\section{Cytotoxic Effects of Zoledronic Acid on Human Epithelial Cells and Gingival Fibroblasts}

Fernanda Gonçalves Basso ${ }^{1}$, Taisa Nogueira Pansani², Camila Fávero de Oliveira $^{3}$, Ana Paula Silveira Turrioni2, Diana Gabriela Soares², Josimeri Hebling $^{2}$, Carlos Alberto de Souza Costa ${ }^{2}$
'UNICAMP - University of Campinas, Piracicaba School of Dentistry, Piracicaba, SP, Brazil 2UNESP - Univ Estadual Paulista, Araraquara School of Dentistry, Araraquara, SP, Brazil ${ }^{3}$ Laboratory of Genetics, Butantan Institute/Departament of Morphology of UNIFESP - Federal University of São Paulo, São Paulo, SP, Brazil

Correspondence: Prof. Dr. Carlos Alberto de Souza Costa, Rua Humaitá, 1680. Centro, 14801-903 Araraquara, SP, Brasil. Tel.:+55-16-3301-6477. e-mail: casouzac@foar.unesp.br
Bisphosphonate-induced osteonecrosis has been related to the cytotoxicity of these drugs on oral mucosa cells. A previous study showed that $5 \mu \mathrm{M}$ of zoledronic acid (ZA), a nitrogen-containing bisphosphonate, is the highest concentration of this drug found in the oral cavity of patients under treatment. Therefore, in order to simulate an osteonecrosis clinical condition, the aim of this study was to evaluate the highest concentration of ZA applied on human epithelial cells ( $\mathrm{HaCaT}$ ) and gingival fibroblasts. For this purpose, cells $\left(3 \times 10^{4}\right.$ cells $\left./ \mathrm{cm}^{2}\right)$ were seeded in wells for $48 \mathrm{~h}$ using complete culture medium (cDMEM). After $48 \mathrm{~h}$ incubation, the cDMEM was replaced by fresh serum-free culture medium (DMEM-FBS) in which the cells were maintained for additional $24 \mathrm{~h}$. Then, $5 \mu \mathrm{M}$ ZA were added to the DMEM-FBS and the cells incubated in contact with the drug for $48 \mathrm{~h}$. After this period, the number of viable cells (trypan blue), cell viability (MTT assay), total protein (TP) production and cell morphology (SEM analysis) were assessed. Data were analyzed statistically by Mann-Whitney, ANOVA and Tukey's test $(\alpha=0.05)$. ZA caused a significant reduction in the number of viable cells and decreased the metabolic activity of both cell lines. However, decrease of TP production occurred only in the epithelial cell cultures. Morphological alterations were observed in both cell types treated with ZA. In conclusion, ZA (5 $\mu \mathrm{M})$ was cytotoxic to human epithelial cells and gingival fibroblast cultures, which could be associated, clinically, with the development of bisphosphonateinduced osteonecrosis.
Key Words: bisphosphonates, cytotoxicity, epithelial cells, fibroblasts.

\section{Introduction}

Bisphosphonates are a class of synthetic analogs of pyrophosphate, which have been widely used for treatment of different diseases characterized by intense bone resorption, such as Paget's disease, osteoporosis, multiple myeloma, bone metastases of breast and prostate tumors (1-3). These drugs inhibit bone resorption mainly by inhibiting osteoclast differentiation and activity (4).

Nitrogen-containing bisphosphonates are more potent than non-nitrogenous bisphosphonates because their greater affinity for hydroxyapatite increases their adhesion to mineralized tissues (5). Recently, bisphosphonate therapy has been associated with the development of osteonecrosis in the oral cavity (5-7).

Bisphosphonate-induced osteonecrosis is characterized by exposed bone in the oral cavity, which persists for 6 to 8 weeks without healing in patients who have been or are currently under bisphosphonate therapy and have no history of radiation therapy to the jaws (6). The etiopathogenesis of this condition has been related with several factors such as type of bisphosphonate, dose, treatment duration, and presence of associated local trauma, bacterial biofilms and local infections $(6,7)$.
Some authors have recently hypothesized that the development of osteonecrosis induced by bisphosphonate could be related to a cytotoxic effect of this drug to oral mucosa cells (8-10). Zoledronic acid (ZA) is a highly potent nitrogen-containing bisphosphonate with a high capacity to adhere to the hydroxyapatite of mineralized dental tissues, and therefore has frequently been associated with the development of osteonecrosis $(5,11,12)$.

Because of the occlusal forces during the process of mastication, bone tissue of the jaws is under constant remodeling (12). In addition, traumas and local infections are also frequent in the jaws and periodontal disease is one of the main causes of bone resorption (13). Therefore, all these factors, alone or in combination, could promote the release of bisphosphonates during bone resorption and remodeling processes (6). The local release of large amounts of bisphosphonates may cause toxic effects to the oral mucosa cells adjacent to the bone tissue, resulting in loss of bone tissue lining (12). Other factors could also act, like biofilm formation on bone tissue (14), perpetuating bone exposure in the oral cavity (6).

Considering that little is known about the negative effects of bisphosphonates on cells of the mucosal lining of the oral cavity, the aim of this study was to evaluate in 
vitro the potential toxic effects of ZA on epithelial cells and gingival fibroblast cultures.

\section{Material and Methods Cell Culture}

All experiments were performed using cultures of human epithelial cells (HaCaT-CLS 300493) and gingival fibroblasts (continuous cell line; Ethics Committee 64/99-Piracicaba Dental School, UNICAMP, Brazil). The cells were cultured in Dulbecco's Modified Eagle's Medium (DMEM; Sigma-Aldrich, St. Louis, MO, USA) supplemented with 10\% fetal bovine serum (FBS; Gibco, Grand Island, NY, USA), with $100 \mathrm{IU} / \mathrm{mL}$ penicillin, $100 \mu \mathrm{g} / \mathrm{mL}$ streptomycin and $2 \mathrm{mM} / \mathrm{L}$ glutamine (Gibco) and maintained in a humidified incubator with $5 \% \mathrm{CO}_{2}$ and $95 \%$ air at $37^{\circ} \mathrm{C}$ (Isotemp; Fisher Scientific, Pittsburgh, PA, USA) Epithelial cells and gingival fibroblasts $\left(3 \times 10^{4}\right.$ cells/ $\left./ \mathrm{cm}^{2}\right)$ were seeded on sterile 24-well acrylic plates (Costar Corp., Cambridge, MA, USA) using plain DMEM supplemented with 10\% FBS for $48 \mathrm{~h}$. Thereafter, the culture medium was replaced by serum-free plain DMEM.

\section{ZA on Epithelial Cells and Gingival Fibroblast Cell Cultures}

After the $24 \mathrm{~h}$ of culture in serum-free DMEM, $5 \mu \mathrm{M}$ ZA (Zometa 4 mg; Novartis Biociências S.A., São Paulo, SP, Brazil) were added to the culture medium. This concentration was chosen based on a study by Scheper et al. (10), who reported that $5 \mu \mathrm{M}$ was the highest ZA concentration (range from 0.7 to $4.6 \mu \mathrm{M}$ ) found in alveolar bone samples and saliva of patients under treatment with this drug. The culture medium with the drug remained in contact with the cells in the incubator with $5 \% \mathrm{CO}_{2}$ and $95 \%$ air at $37^{\circ} \mathrm{C}$ for $48 \mathrm{~h}$, after which time the cytotoxic effects of ZA were evaluated as described below.

\section{Viable Cell Counting (Trypan Blue Assay)}

Trypan blue assay was used to evaluate the number of viable cells in the culture after ZA treatment. This test is based on the fact that the trypan blue dye can penetrate only permeable membranes of lethally damaged (dead) cells, changing their color into blue, which is detectable under optical microscopy $(15,16)$. After $48 \mathrm{~h}$ of treatment, cell counting was evaluated in experimental and control groups for each cell line. For that, cells were detached using $0.25 \%$ trypsin (Invitrogen, Carlsbad, CA, USA), for $10 \mathrm{~min}$. Then $50 \mu \mathrm{L}$ aliquots of this cell suspension were added to $50 \mu \mathrm{L}$ of $0.04 \%$ trypan blue dye (Sigma Aldrich) and the resulting solution was maintained at room temperature for $2 \mathrm{~min}$. Next, the cells were counted with an automated cell counter (TC10 Automated Cell Counter 145-0001; Bio-Rad Laboratories, Inc., Hercules, CA, USA). For each sample, the cell counter provided the total number of cells, the number of viable cells and their percentages.

\section{Analysis of Cell Viability (MTT Assay)}

Cell viability was evaluated using the methyltetrazolium (MT) assay (17-19). This test determines the activity of SDH enzyme, which is a measure of cellular (mitochondrial) respiration, and can be considered as the metabolic rate of cells. After $48 \mathrm{~h}$ of incubation of the cells in contact with DMEM alone (control group) or containing ZA at $5 \mu \mathrm{M}$ concentration (experimental group), the culture medium was aspirated and replaced by $900 \mu \mathrm{L}$ of fresh DMEM plus $100 \mu \mathrm{L}$ of MT solution (Sigma-Aldrich) (5 $\mathrm{mg} / \mathrm{mL}$ sterile PBS). The cells in contact with the MTT solution were incubated at $37{ }^{\circ} \mathrm{C}$ for $4 \mathrm{~h}$. Thereafter, the culture medium with the MTT solution was aspirated and replaced by $700 \mu \mathrm{L}$ of acidified isopropanol solution (0.04 $\mathrm{N} \mathrm{HCl}$ ) in each well to dissolve the violet formazan crystals producing a homogenous bluish solution resulting from the cleavage of the MTT salt ring by the SDH enzyme present in the mitochondria of viable cells. After agitation and confirmation of the homogeneity of the solutions, three $100 \mu \mathrm{L}$ aliquots of each well were transferred to a 96-well plate (Costar Corp., Cambridge, MA, USA). Cell viability was evaluated by spectrophotometry as being proportional to the absorbance measured at $570 \mathrm{~nm}$ wavelength with an ELISA plate reader (Thermo Plate, Nanshan District, Shenzhen, Guangdong, China). The values obtained from the three aliquots were averaged to provide a single value. The absorbance was expressed in numerical values, which were subjected to statistical analysis to determine the effect of ZA on the viability of the cells. A sample of each group was selected to obtain images of $\mathrm{MT}$ salt impregnation in the cells after the test (Figs. 1 and 2).

\section{Total Protein (TP) Production}

TP production was evaluated according to the Read and Northcote (20) protocol, as previously described by Oliveira et al. (21). After 48-h incubation of the cells in contact with DMEM alone (control group) or containing ZA (experimental group), the culture medium was aspirated and $1 \mathrm{~mL}$ of $0.1 \%$ sodium lauryl sulphate (Sigma Aldrich) was added to each well and maintained for $40 \mathrm{~min}$ at room temperature to produce cell lysis, followed by the addition of $1 \mathrm{~mL}$ of Lowry reagent solution (Sigma Aldrich). After $20 \mathrm{~min}$ at room temperature, $500 \mu \mathrm{L}$ of Folin-Ciocalteau's phenol reagent solution (Sigma Aldrich) were added to each sample and homogenized. Thirty minutes later, three $100 \mu \mathrm{L}$ aliquots of each tube were transferred to a 96-well plate and the absorbance of the test was measured at 655 $\mathrm{nm}$ wavelength with the ELISA plate reader (Thermo Plate). Total protein production was calculated from a standard 
curve created using known protein concentrations.

\section{Analysis of Cell Morphology by Scanning Electron Microscopy (SEM)}

SEM analysis was used to identify possible morphological alterations caused by ZA on epithelial cell and gingival fibroblast cell cultures. The following protocol used in previous studies was employed $(17,19)$. Sterile $13-\mathrm{mm}$ diameter cover glasses (Fisher Scientific) were placed on the bottom of the wells immediately before seeding the cells. After $48 \mathrm{~h}$ of incubation in contact with DMEM alone (control group) or containing ZA (experimental group), the culture medium was aspirated and the cells were fixed in 1 $\mathrm{mL}$ of 2.5\% glutaraldehyde (Sigma-Aldrich) in PBS for $1 \mathrm{~h}$ at

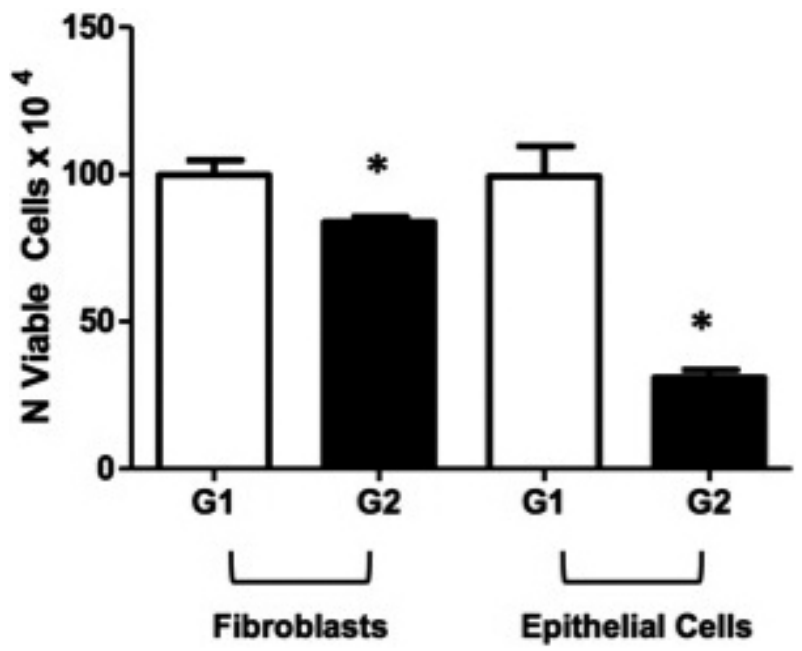

Figure 1. Number of viable cells in the human gingival fibroblasts and epithelial cell cultures, with and without zoledronic acid treatment (G1-control group; G2-ZA $5 \mu \mathrm{M}$ ). room temperature. Then, the glutaraldehyde was aspirated and the cells were washed with PBS and post-fixed with 1\% osmium tetroxide (Electron Microscopy Science, Fort Washington, PA, USA) for $1 \mathrm{~h}$ at room temperature. The cells that remained adhered to the glass substrate were washed again with PBS and distilled water for two consecutive times for 5 and 15 min respectively, and then dehydrated in a series of increasing ethanol concentrations $(30,50$ and $70 \%$, one time for $30 \mathrm{~min}$ each; 95 and 100\%, two times for 60 min each). The cells were immersed for 60 min (three 20min changes) in $200 \mu \mathrm{L}$ of 1,1,1,3,3,3-hexamethyldisilazane (HMDS; ACROS Organics, New Jersey, NY, USA). Finally, the cells were mounted on metallic stubs, stored in a desiccator for $24 \mathrm{~h}$ and sputter-coated with a 20-nm gold-palladium layer (SDC 050; Bal-Tec AG, Balzers, Germany), and their morphology was examined with a scanning electron microscope (JEOL USA Inc., Peabody, MA, USA).

\section{Statistical Analysis}

For the epithelial cell culture, after assessing the distribution (Shapiro-Wilk, $p>0.05$ ) and homogeneity of variances (Levene, $p>0.05$ ) (SPSS), the viable cell number (trypan blue assay), cell viability (SDH production) and TP production data were analyzed by the nonparametric Mann-Whitney test.

For the gingival fibroblast cell cultures, after analysis of distribution (Shapiro-Wilk, $p>0.05$ ) and homogeneity of variances (Levene, $p>0.05$ ), the viable cell number (trypan blue assay), cell viability (SDH production) and TP production data were independently subjected to one-way analysis of variance (treatment: control x $5 \mu \mathrm{M} Z A$ ). As the null hypothesis of absence of differences among the groups was rejected, additional Tukey's tests were applied. A significance level of 5\% was set for all analyses.
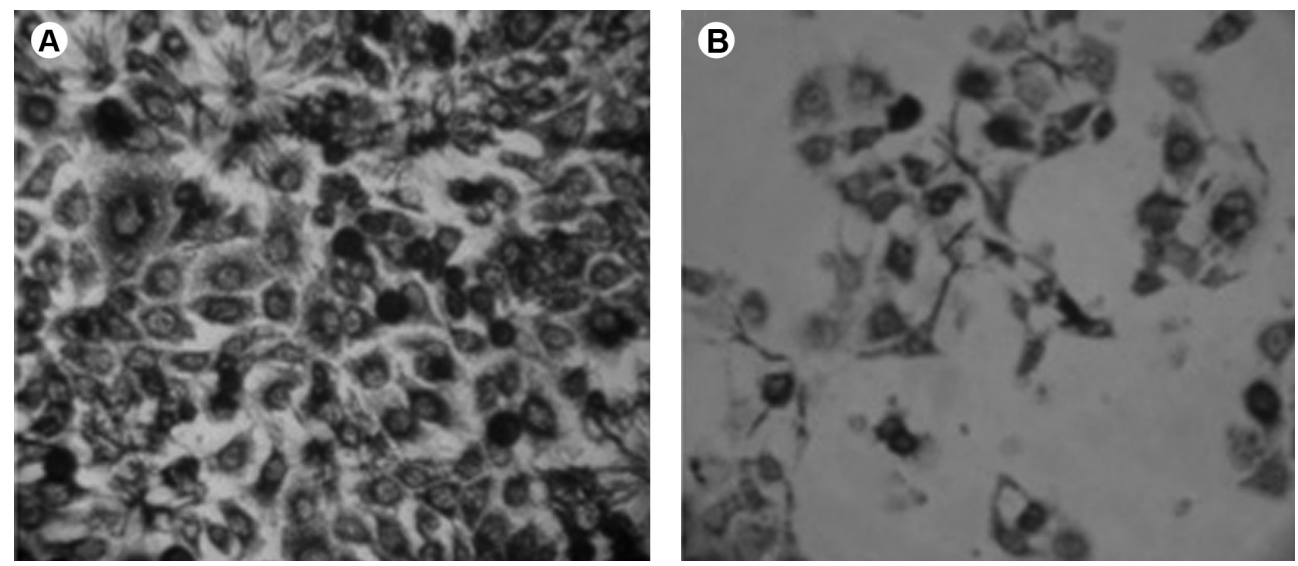

Figure 2. Photomicrographs of human epithelial cells (HaCaT) under light inverted microscopy (TS100; Nikon Corp, Tokyo, Japan). A: In control group, a large number of elongated cells near to confluence covering the surface of the glass substrate are observed. B: When the cells were exposed to ZA, an intense reduction in the number of viable cells, leaving wide cell-free glass substrate zones, can be seen. Original magnification 10x. 


\section{Results}

After the incubation period with DMEM containing $Z A$, both cell lines presented a significant reduction in the number of viable cells compared to the control group $(p<0.05)$ (Fig. 1).

The application of ZA reduced significantly the viability (SDH production) of epithelial cells (Table 1 and Fig. 2) and gingival fibroblasts (Table 2 and Fig. 3 ) compared to the control group $(\mathrm{p}<0.05)$.

The contact of $5 \mu \mathrm{M}$ ZA with the epithelial cells for 48 $\mathrm{h}$ also reduced significantly TP production compared to the control group $(p<0.05)$ (Table 1). However, for the gingival fibroblasts, no statistically significant difference occurred between the treated and control groups ( $p>0.05$ ) (Table 2).

The morphological analysis of epithelial cells and gingival fibroblasts by SEM after treatment with $5 \mu \mathrm{M}$ ZA showed that the drug promoted severe morphological alterations in both cell types. In the treated groups, the cells exhibited a shrunken cytoplasm and a number of cells detached from the glass substrate, leaving wide cell-free zones (Figs. 4 and 5).

\begin{tabular}{|c|c|c|}
\hline Groups & Cell viability (\%) & $\begin{array}{l}\text { Total protein } \\
\text { production }(\%)\end{array}$ \\
\hline Control & $100(96.1-104.04)^{\mathrm{A}}$ & $100(93.28-121.82)^{\mathrm{A}}$ \\
\hline Zoledronic acid & $33.28(17.09-51.27)^{\text {В }}$ & $65.31(59.71-77.64)^{\text {в }}$ \\
\hline
\end{tabular}

All values are given as medians (percentile 25-percentile 75 ). In each column, groups identified with different letters are statistically different (Mann-Whitney, p<0.05).

\section{Discussion}

The effects of bisphosphonates on different cell types have been extensively investigated. However, only a few studies have evaluated the effects of a bisphosphonate on two cell types using the same dose and incubation time $(9,12,22)$.

The present study evaluated the effect of $Z A$, a highly potent nitrogen-containing bisphosphonate, on epithelial cells and gingival fibroblasts with the main goal of determining whether the drug concentration $(5 \mu \mathrm{M})$ found in the alveolar bone tissue of patients subjected to ZA therapy (10) could have toxic effects to cultures of these cell lines.

The results of the present investigation are relevant because of the high incidence of bisphosphonate-induced osteonecrosis and due to the fact that the etiopathogenesis and treatment protocols for this kind of disease have not been completely elucidated. Therefore, knowledge of the etiopathogenesis of this condition is very important to prevent and treat osteonecrosis lesions improving the

Table 2. Data of cell viability (percentage values) and total protein production (percentage values) of human gingival fibroblast cell cultures exposed to zoledronic acid

\begin{tabular}{lcc}
\hline Groups & Cell viability (\%) & Total protein production \\
\hline Control & $100(20.17)^{\mathrm{A}}$ & $100(31.83)^{\mathrm{A}}$ \\
Zoledronic acid & $60.52(16.66)^{\mathrm{B}}$ & $106.83(30.27)^{\mathrm{A}}$ \\
\hline
\end{tabular}

All values are given as mean (standard deviation), $n=12$, for both products of cell metabolism. Means followed by same letters in columns do not differ significantly (Tukey's test, $p>0.05$ ).
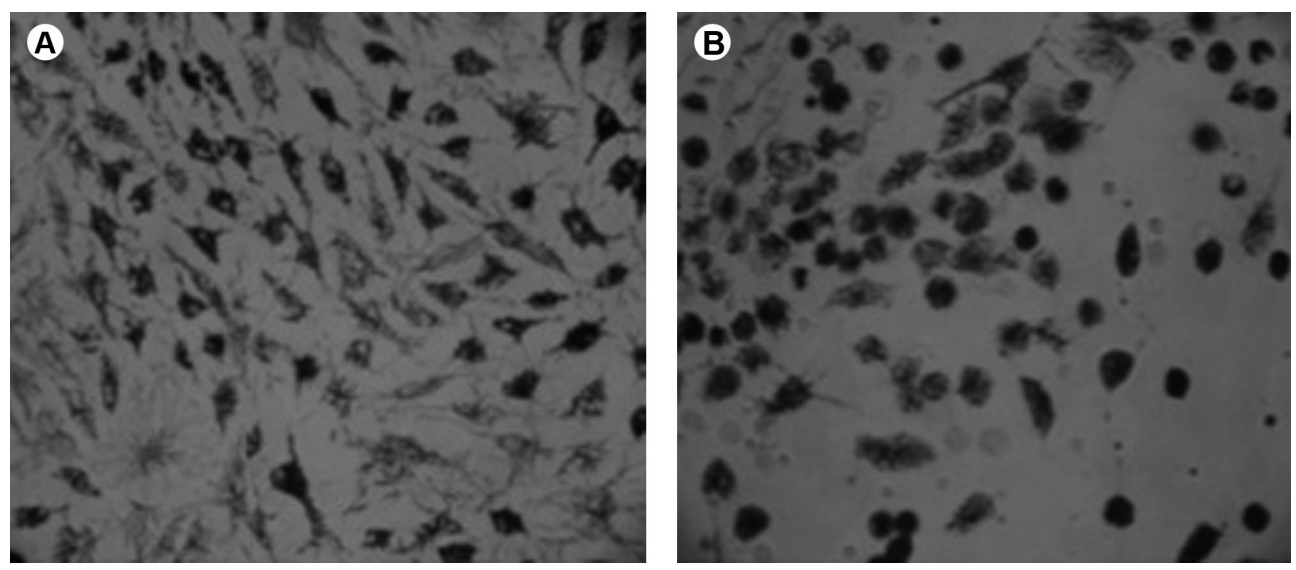

Figure 3. Photomicrographs of human gingival fibroblasts under light inverted microscope (TS100; Nikon). A: In control group, there are a number of cells near to the confluence covering the surface of glass substrate. B: In the group treated with zoledronic acid, a significant reduction in the number of viable cells occurred. The cells adhered to the substrate exhibit a round shape. Original magnification 10x. 
patients' quality of life.

Concerning the methodology employed, epithelial cells and gingival fibroblasts were used, since these cell populations play an active role on oral mucosa homeostasis and tissue healing (23). In addition, the interaction between epithelial cells and fibroblasts is directly related to the oral mucosa repair (23). However, in spite of the interesting data presented in previous studies $(10,24)$, only few researchers compared the toxicity of bisphosphonates on epithelial cells and fibroblasts $(9,10)$. This kind of laboratory test is relevant since the toxic effect of bisphosphonates, especially ZA on oral mucosa cells, is the main cause of osteonecrosis development and its maintenance. It should also be reported that the specific ZA concentration used in the present investigation represents the amount of ZA found in saliva and bone of patients under ZA treatment (10). All these facts together could justify the development of the present in vitrostudy, which definitively contributes to the research field.

Overall, the results showed that ZA reduced significantly the number of viable cells of both cell lines and decreased the viability of epithelial cells and fibroblasts by $70 \%$ and $40 \%$, respectively. Previous studies demonstrated, in the same way as observed in the present investigation, the sensitivity of human epithelial cells and fibroblasts to treatment with ZA. Scheper et al. (9) evaluated the effects of ZA $(0.25$ to $3 \mu \mathrm{M})$ on epithelial cells and fibroblast cultures and observed a similar effect for both cell types, with a significant decrease of cell proliferation at concentrations above $1 \mu \mathrm{M}$. In a subsequent study, the same authors confirmed their previous findings and also demonstrated a significant increase in the apoptotic ratio in the epithelial cells after treatment with ZA at concentrations above $1 \mu \mathrm{M}$ (10). In a recent study, Ravosa et al. (24) found a greater sensitivity of the epithelial cells to the cytotoxicity of ZA, with a significant decrease in cell viability after 48-h
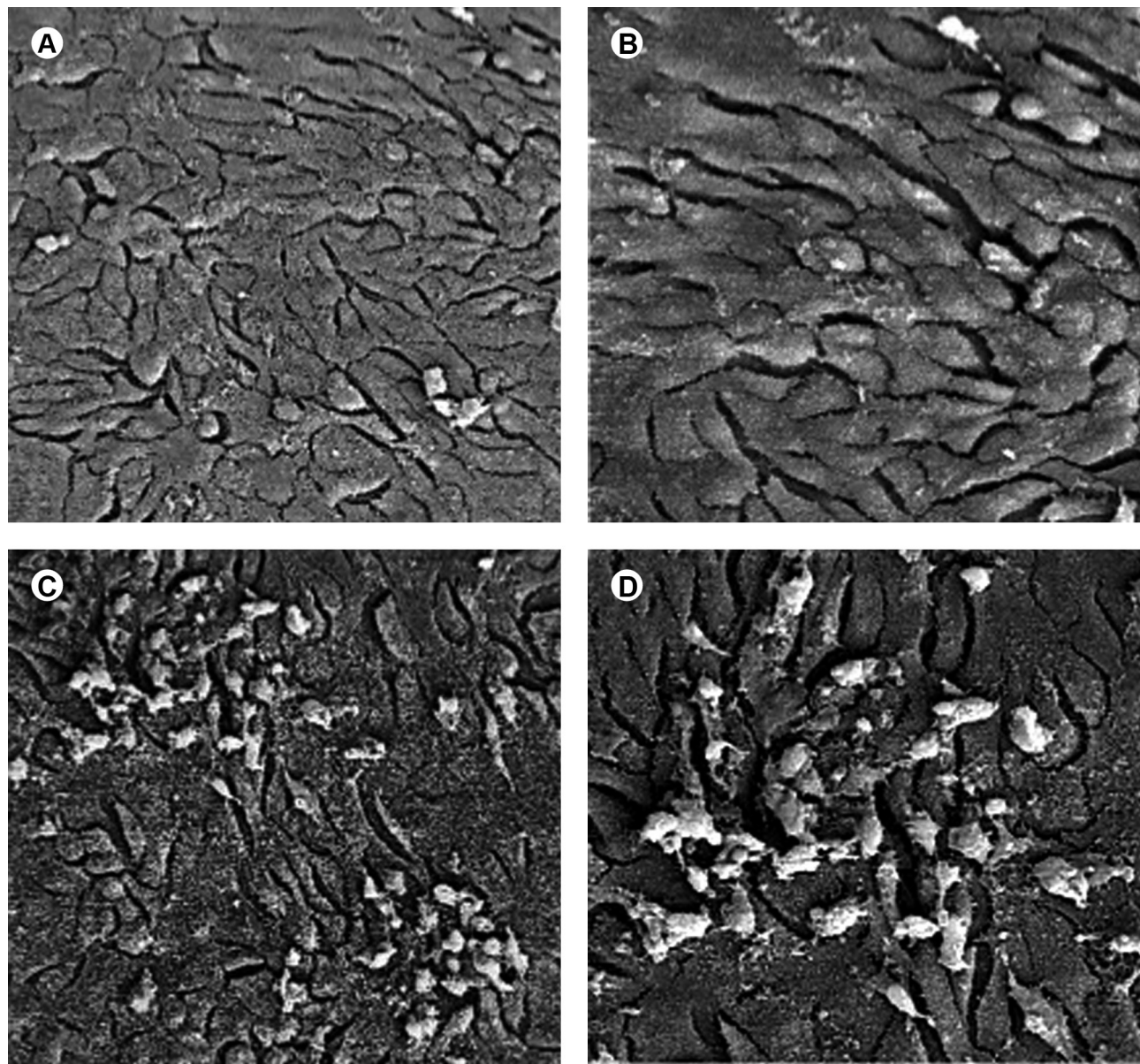

Figure 4. SEM micrographs showing the morphology of normal epithelial cells (A/B - control group) and ZA-treated epithelial cells (C/D - experimental group). A: The cells exhibit discrete fusiform morphology near to confluence on the substrate. SEM, Original magnification 200x. B: High magnification of the Figure 4A. Note that the cells close to confluence present slightly elongated morphology. SEM, Original magnification 500x. C: A number of epithelial cells with shrunken cytoplasm compared to the control group can be observed on the glass substrate. SEM, Original magnification 200x. D: Detail of 'C'. Fragments of dead cells that detached from the substrate can be seen among epithelial cells with cytoplasm shrinkage. SEM, Original magnification 500x. 
incubation with the drug at concentrations higher than 10 $\mu \mathrm{M}$. For gingival fibroblasts, on the other hand, the same effect was observed only for concentrations above $30 \mu \mathrm{M}$. The divergence of results in these studies may be due to the use of different concentrations of the drug, contact times and cell lines.

In the present study, a significant decrease in TP production by the epithelial cells was observed, suggesting that bisphosphonates can reduce protein production of this cell type and may have a negative effect on the repair and healing of oral tissues. The same result, however, was not observed for the gingival fibroblasts treated with ZA, which confirms that different cell lines can have different responses to the drug.

Agis et al. (25) evaluated the effect of ZA $(30 \mu \mathrm{M})$ on gingival fibroblast cultures and also found a significant decrease of cell viability and proliferation. However, they found a decrease of TP production by the fibroblasts, which differ from the findings of the present study. These divergent results may be related to the higher ZA concentrations used by those authors, as a dose-dependent cytotoxicity of bisphosphonates on different cell cultures has been demonstrated $(9,12,24)$. On the other hand, Walter et al. (12) found an $80 \%$ decrease of viability (MT assay) of fibroblasts incubated with $5 \mu \mathrm{M}$ ZA for $24 \mathrm{~h}$, while in the present study, a 48-h incubation time caused a $40 \%$ decrease in gingival fibroblast viability. These results suggest that the cytotoxicity of the ZA is not time-dependent.

In the same way as in the present study, Scheper et al. (9) evaluated the effect of ZA on the death and proliferation of epithelial cells and fibroblasts, but using lower concentrations of the drug. The authors found that ZA produced a dose-dependent increase in apoptotic ratios in both cell lines and observed a significant decrease of cell proliferation only for concentrations higher than $1 \mu \mathrm{M}$.

The analysis of cell morphology by SEM revealed the occurrence of death with consequent detachment from the glass substrate of some epithelial cells and
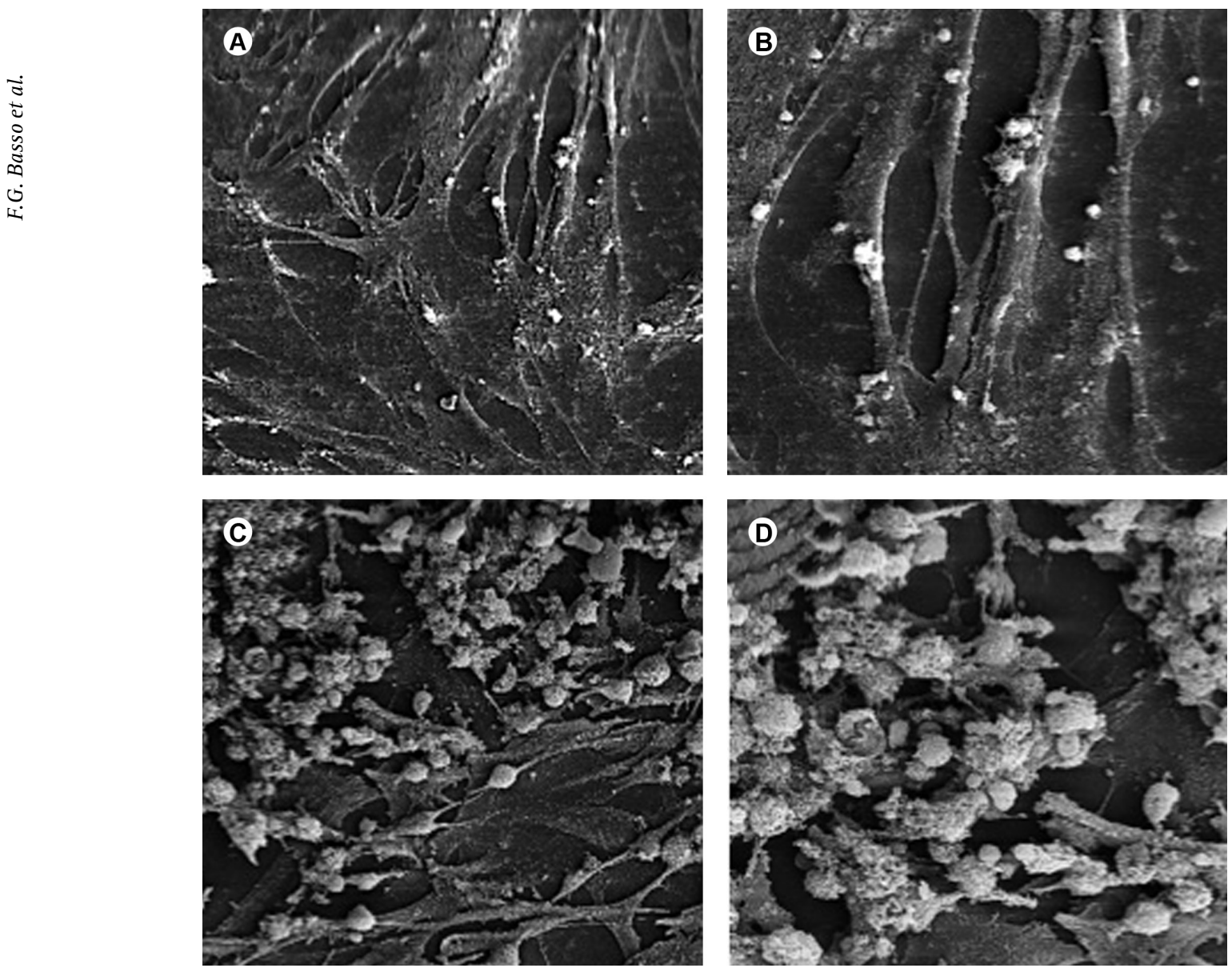

Figure 5. SEM micrographs showing the morphology of normal gingival fibroblasts (A/B - control group) and ZA-treated fibroblasts (C/D - experimental group). A: Numerous fibroblasts with discrete fusiform morphology adhered to the substrate are observed. Original magnification 200x. B: Detail of ' $A$ ' showing fibroblasts with a wide cytoplasm. Original magnification 500x. C: Although several fibroblasts remained adhered to the substrate, numerous flake structures can be observed. Original magnification 200x. D: High magnification of ' $C$ ', in which round-shaped cells with disrupted cytoplasmic membrane among rests of dead fibroblast that detached from the glass substrate can be seen. Original magnification 500x. 
fibroblasts treated with ZA. In addition, most cells that remained adhered to the substrate presented remarkable morphological alterations. These results confirm that the concentration used in the present study $(5 \mu \mathrm{M})$ caused cytotoxic effects to the epithelial cell and gingival fibroblast cultures, confirming the results of the MTT assay used to evaluate the viability of both cell lines after the treatment.

The etiopathogenesis of bisphosphonates-induced osteonecrosis has not yet been elucidated. However, knowing that the alveolar bone is constantly remodeling $(12,13)$, bisphosphonates that adhere to the bone of patients under ZA therapy can be released from mineralized tissues during the bone formation and resorption processes. Therefore, the accumulation of bisphosphonates at high concentrations in the tissues may have toxic effects to the cells in this microenvironment, such as fibroblasts, endothelial cells, osteoblasts and epithelial cells $(8,12)$. In the present in vitro study, the concentration of ZA detected in the bone tissue of patients subjected to bisphosphonate therapy $(5 \mu \mathrm{M})$ (10) caused cytotoxic effects to epithelial cell and gingival fibroblast cell cultures in vitro. However, these preliminary results cannot be extrapolated to the clinical situations until further research is done. Other studies are necessary to investigate the effects of bisphosphonates on the oral microenvironment to understand the etiopathogenesis of bisphosphonate-induced osteonecrosis and, in the future, prevent the occurrence of this condition or at least use more effective therapies with less severe side effects.

Under the conditions of this study, it may be concluded that ZA ( $5 \mu \mathrm{M})$ causes toxic effects to cultures of human epithelial cells and gingival fibroblasts, which could be associated with the occurrence of bisphosphonate-induced osteonecrosis in patients under therapy with this drug.

\section{Resumo}

A osteonecrose induzida por bisfosfonatos tem sido associada a um efeito citotóxico destes medicamentos sobre as células da mucosa oral. Um estudo recente demonstrou que $5 \mu \mathrm{M}$ de ácido zoledrônico (AZ), um potente bisfosfonato nitrogenado, foi a maior concentração encontrada na cavidade oral da pacientes em tratamento com este medicamento. Portanto, para simular esta condição in vivo, o objetivo deste estudo foi avaliar o efeito da aplicação desta concentração de AZ sobre células epiteliais ( $\mathrm{HaCaT}$ ) e fibroblasto de gengiva. As células foram semeadas $\left(3 \times 10^{4}\right.$ células $\left./ \mathrm{cm}^{2}\right)$ e incubadas por $48 \mathrm{~h}$ em placas de 24 compartimentos, utilizando meio de cultura completo (cDMEM). Após permanecer por $24 \mathrm{~h}$ em DMEM sem soro fetal bovino (DMEM-SFB), 5 $\mu \mathrm{M}$ do $\mathrm{AZ}$ foram adicionados a este meio de cultura, o qual foi incubado em contato com as células por $48 \mathrm{~h}$. Após este periodo, foram avaliados o número de células viáveis (trypan blue), viabilidade celular (teste de MTT), produção de proteina total e a morfologia celular (MEV). Os dados obtidos foram submetidos aos testes estatísticos de Mann-Whitney e ANOVA complementada por testes de Tukey $(p>0,05)$. Foi demonstrado que o AZ causou diminuição significativa no número de células viáveis, além de redução do metabolismo celular para ambos os tipos celulares avaliados. Porém, redução na produção de proteína total ocorreu apenas para as células epiteliais. Alterações morfológicas foram observadas em ambos os tipos celulares tratados com AZ. Estes dados científicos indicam que a concentração de $A Z$ avaliada neste estudo $(5 \mu \mathrm{M})$ apresenta ação citotóxica sobre células epiteliais e fibroblastos de gengiva, o que poderia estar associado, clinicamente, ao desenvolvimento da osteonecrose induzida por bisfosfonatos.

\section{Acknowegements}

The authors acknowledge the Fundação de Amparo à Pesquisa do Estado de São Paulo - FAPESP (grants: 2009/54722-1 and BP.DR: 2009/ 52326-1) and the Conselho Nacional de Desenvolvimento Científico e Tecnológico - CNPq (Grant: 301291/2010-1) for the financial support.

\section{References}

1. Civitelli R, Napoli N, Armamento-Villareal R. Use of intravenous bisphosphonates in osteoporosis. Curr Osteoporos Rep 2007;5:8-13.

2. Cohen SB. An update on bisphosphonates. Curr Rheumatol Rep 2004;6:59-65

3. Rogers MJ, Watts DJ, Russel RG. Overview of bisphosphonates. Cancer 1997;80:1652-1660.

4. Rogers MJ, Gordon S, Benford HL, Coxon FP, Luckman SP, Monkkonen J, et al.. Cellular and molecular mechanisms of action of bisphosphonates. Cancer Supl 2000;88:2961-2978.

5. Lawson MA, Xia Z, Barnett BL, Triffitt JT, Phipps RJ, Dunford JE, et al.. Differences between bisphosphonates in binding affinities for hydroxyapatite. J Biomed Mater Res Part B: Appl Biomater 2010;92:149-155.

6. Allen MR, Burr DB. The pathogenesis of bisphosphonate-related osteonecrosis of the jaw: so many hypotheses, so few data. J Oral Maxillofac Surg 2009;67:61-70.

7. Otto S, Pautke C, Opelz C, Wesphal I, Drosse, I, Swager J, et al. Osteonecrosis of the jaw: effects of bisphosphonate type, local concentration, and acidic milieu on the pathomechanism. J Oral Maxillofac Surg 2010;68:2837-2845.

8. Reid IR, Booland MJ. Is bisphosphonate-associated osteonecrosis of the jaw caused by soft tissue toxicity? Bone 2007;41:318-320.

9. Scheper MA, Badros A, Chausparat R, Cullen KJ, Meiller TF. Effect of zoledronic acid on oral fibroblasts and epithelial cells: a potential mechanism of bisphosphonate-associated osteonecrosis. Br J Haematol 2009;144:667-676

10. Scheper MA, Badros A, Salama AR, Wartburton G, Cullen KJ, Weikel DS, et al.. A novel bioassay model to determine clinically significant bisphosphonate levels. Support Care Cancer 2009;17:1553-1557.

11. Ruggiero SL, Mehrotra B, Rosenberg TJ, Engroff SL. Osteonecrosis of the jaws associated with the use of bisphosphonates: a review of 63 cases. J Oral Maxillofac Surg 2004;62:527-534.

12. Walter $C$, Klein MO, Pabst A, Al-Nawas B, Duscher H, Ziebart T. Influence of bisphosphonates on endothelial cells, fibroblasts, and osteogenic cells. Clin Oral Investig 2010;14:35-41.

13. Kumar SKS, Gorur A, Schaauddin C, Shuler CF, Costerton JW, Sedghizadeh PP. The role of microbial biofilms in osteonecrosis of the jaw associated with bisphosphonate therapy. Curr Osteoporos Rep 2010;8:40-48

14. Aas JA, Paster BJ, Stokes LN, Olsen I, Dewhirst FE. Defining the normal bacterial flora of the oral cavity. J Clin Microbiol 2005;43:5721-5732.

15. Basso FG, Pansani TN, Turrioni APS, Bagnato VS, Hebling J, de Souza Costa CA. In vitro wound healing improvement by low-level laser therapy application in cultured gingival fibroblasts. Int J Dent 2012 [Epub ahead of print. DOI: 10.1155/2012/719452].

16. Wiegand $\mathrm{C}$, Hipler U. Methods for the measurement of cell and tissue compatibility including tissue regeneration process. GMS Krankenhhyg Interdiszip 2008;3:1863-5245.

17. Basso FG, Oliveira CF, Kurachi C, Hebling J, de Souza Costa CA. Biostimulatory effect of low-level laser therapy on keratinocytes in vitro. Lasers Med Sci 2013;28:367-374.

18. De Souza Costa CA, Duarte PT, de Souza PP, Giro EM, Hebling J. Cytotoxic effects and pulpal response caused by a mineral trioxide aggregate formulation and calcium hydroxide. Am J Dent 2008;21:255-261. 
19. Oliveira CF, Basso FG, Lins ECC, Kurachi C, Hebling J, Bagnato VS, et al.. Increased viability of odontoblast-like cells subjected to low-level laser irradiation. Laser Phys 2010;20:1659-1666.

20. Read SM, Northcote DH. Minimization of variation in the response to different proteins of the Coomassie blue $\mathrm{G}$ dye-binding assay for protein. Anal Biochem 1981;116:53-64.

21. Oliveira CF, Basso FG, Lins EC, Kurachi C, Hebling J, Bagnato VS, et.al.. In vitro effect of low-level laser on odontoblast-like cells. Laser Phys Lett 2011;8:155-163.

22. Simon MJK, Niehoff $P$, Kimming B, Wiltfang J, Açil Y. Expression profile and synthesis of different collagen types I, II III and V of human gingival fibroblasts, osteoblasts, ans $\mathrm{SaO}$ - 2 cells after bisphosphonate treatment. Clin Oral Investig 2010;14:51-58.
23. Migliorati CA, Siegel MA, Elting LS. Bisphosphonate-associated osteonecrosis: a long-term complication of bisphosphonate treatment. Lancet Oncol 2006; 7:508-514.

24. Werner S, Krieg T, Smola H. Keratinocyte-fibroblast interactions in wound healing. J Investigative Dermatol 2007;127:998-1008.

25. Ravosa MJ, Ning J, Liu Y, Stack MS. Bisphosphonate effects on the behavior of oral epithelial cells and oral fibroblasts. Arch Oral Biol 2011;56:491-498.

Received April 10, 2013 Accepted December 12, 2013 